\title{
Selective Estrogen Receptor Modulator Raloxifene as a Possible Regulator of Arginine Vasopressin
}

\author{
Denise Börzsei ${ }^{1}$, Renáta Szabó ${ }^{1,2}$, Alexandra Hoffmann ${ }^{1}$, Krisztina Kupai ${ }^{1}$, Anikó Magyariné Berkó ${ }^{1}$, \\ Csaba Varga ${ }^{1}$ and Anikó Pósa ${ }^{1,2 *}$ \\ ${ }^{1}$ Department of Physiology, Anatomy and Neuroscience, Faculty of Science and Informatics, Hungary \\ ${ }^{2}$ Department of Physiology, Anatomy and Neuroscience, Interdisciplinary Excellence Centre, Hungary
}

*Corresponding author: Anikó Pósa, Department of Physiology, Anatomy and Neuroscience, Szeged, Hungary

\begin{tabular}{|c|c|}
\hline ARTICLE INFO & ABSTRACT \\
\hline Received: 慧 April 08, 2019 & Estrogen $\left(E^{2}\right)$ and raloxifene (RAL) have positive impact on the cardiovascular system \\
\hline Published: April 18, 2019 & $\begin{array}{l}\text { throughout the regulation of blood pressure. In this present study we investigated how E2 } \\
\text { deficit influences the level of arginine vasopressin (AVP) in plasma. We also investigated }\end{array}$ \\
\hline $\begin{array}{l}\text { Citation: Denise B, Renáta S, Alex- } \\
\text { andra H, Krisztina K, Anikó Pósa. Se- } \\
\text { lective Estrogen Receptor Modulator } \\
\text { Raloxifene as a Possible Regulator of } \\
\text { Arginine Vasopressin. } \\
\text { Biomed J Sci \& Tech Res } 17(2)-2019 .\end{array}$ & $\begin{array}{l}\text { whether low-dose E } 2 \text { monotherapy or RAL treatment change the AVP content compared } \\
\text { to hormone deficient state. The lack of E2 caused a significant increase in the level of } \\
\text { AVP compared to control group. However, administration of E } 2 \text { and RAL in three different } \\
\text { doses evoked a decrease in the concentration of AVP in plasma. In addition, an inverse } \\
\text { correlation was found between the dose of RAL and AVP levels. These results indicate that } \\
\text { vasopressin expression is regulated by E2 and RAL, suggesting an important role in the } \\
\text { therapy of cardiovascular events. }\end{array}$ \\
\hline
\end{tabular}

Keywords: Raloxifene; Vasopressin; Estrogen deficiency

Abbreviations: $E_{2}$ : Estrogen; RAL: Raloxifene; AVP: Arginine Vasopressin; SERM: Selective Estrogen Receptor Modulators; OVX: Ovariectomized; RIA: Radioimmunoassay

\section{Introduction}

In general, the average life expectancy is increasing worldwide therefore women spend more than one- third of their lives in estrogen deficiency. Several studies confirmed that cardiovascular diseases appear more likely in women over 60 years old than age-matched men [1]. It is also proved that middle-aged women who receive hormone replacement less likely to suffer from circulatory disorders. Although large number of animal studies confirmed the protective effects of estrogen replacement, human clinical researches were inconclusive. Long term hormone administration increases the chance of breast and endometrial carcinoma development [2]. However selective estrogen receptor modulators (SERM) are a class of drugs that have estrogen agonist characteristics in target tissues such as cardiovascular system or central nervous system, they are not oncogenic [3].

The most widely used SERM is raloxifene (RAL), which is proved to have several beneficial effects on the level of lipoprotein(a), serum homocysteine and C-reactive protein [4].
Moreover, it inhibits the lipid peroxidation of blood vessels, platelet aggregation and myointimal proliferation, conclusively the incidence of atherosclerotic processes [5]. Estrogen bound to its receptor modulates the release of arginine vasopressin (AVP), the key molecule in pathogenesis of hypertension and for this reason SERMs can be a potential treatment for postmenopausal women. Hence, the aim of our study was to investigate the possible cardioprotective effect of $\mathrm{E}_{2} / \mathrm{RAL}$ treatment throughout the reduction of AVP.

\section{Materials and Methods \\ Experimental Protocol}

During our experiments female rats weighing 230-250g were used. Animals were kept under standard housing conditions (temperature, light). After one-week acclimatization, animals were randomized into the following groups: fertile female rats (control, CTRL), ovariectomized (OVX), OVX + estrogen $\left(E_{2}\right), O V X+$ raloxifene 
(RAL). In order to achieve estrogen-depleted conditions surgical ovariectomy was performed. During ovariectomy the ovaries on both sides were clamped and removed under anesthesia. After one month of regeneration, the animals were treated with $E_{2}(0,10 \mathrm{mg} /$ $\mathrm{kg} /$ day, per os) or with RAL (in three different doses: $0,11 \mathrm{mg} / \mathrm{kg} /$ day; $0,33 \mathrm{mg} / \mathrm{kg} /$ day; $1,0 \mathrm{mg} / \mathrm{kg} /$ day, per os) for two weeks. All procedures were approved by the Institutional Ethical Committee and were performed in accordance with the guidelines of the European Community.

\section{Measurement of Plasma AVP}

The level of arginine vasopressin (AVP) was determined with Radioimmunoassay (RIA) based on a previously described method [6]. A synthetic AVP (Organon, Oss, The Netherlands, antidiuretic activity $408 \mathrm{IU} / \mathrm{mg}$ ) was used as a reference for antibody production and radio labelling. For immunization animals were received 1,0 mg immunogen emulsified in 1,0ml Freund's adjuvant. The ${ }^{125}$ I labeling of vasopressin was performed by chloramine $\mathrm{T}$ method, then the labeled hormone was purified with reverse phase chromatography. The specific activity of ${ }^{125} \mathrm{I}$ labeled vasopressin was between
49,90 and 61,10 TBq/ mmol. Blood samples were collected after decapitation, stored in polystyrene tubes $(1,40 \mathrm{mg}$ Na2EDTA, 30,0 $\mu \mathrm{l}$ isotonic $\mathrm{NaCl}$ ). After 10 seconds of centrifugation $\left(1000 \mathrm{~g}, 4^{\circ} \mathrm{C}\right)$, samples were stored at $-20^{\circ} \mathrm{C}$ until further measurements.

RIA determination was performed 72 hours after sample collection. Vasopressin extraction was carried out from plasma samples with Amprep C8 minicolumn (RPN 1902, Amersham, Buckinghamshire, United Kingdom). Standard curves were within the range 1,0-128,0pg/assay tube. Reference vasopressin-free dilutions were extracted from homozygotic rats suffered from diabetes insipidus (CPB-TNO, Zeist, The Netherlands). The dry residue was re-dissolved in $125 \mu$ of RIA buffer, then $50 \mu$ l aliquots were used for the RIA in duplicate. The sensitivity of RIA was $1 \mathrm{pg} /$ tube. The level of plasma vasopressin is given in $\mathrm{pg} / \mathrm{ml}$.

\section{Statistical Analysis}

The results are expressed as means \pm S.E.M. Statistical analysis was performed with Mann W. test. A probability level of $\leq 0.05$ was considered as a significant difference.

\section{Results}

\section{The Effects of Estrogen and Raloxifene on Plasma AVP Level in OVX Rats}

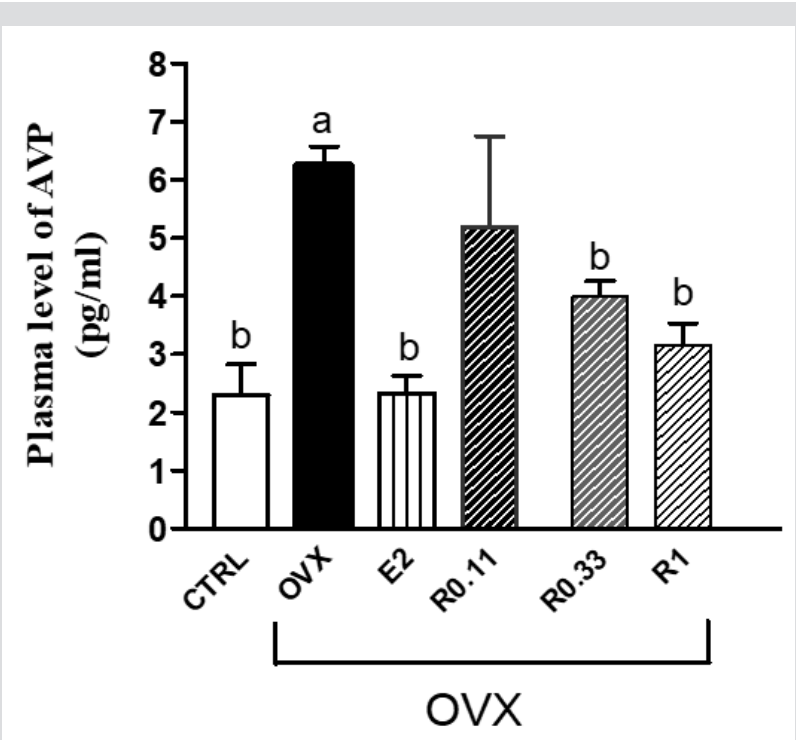

Note: Statistical significance: ${ }^{\mathrm{a}} \mathrm{p}$ : $<0.05$ compared to fertile CTRL rats, ${ }^{\mathrm{b}} \mathrm{p}$ : $<0.05$ compared to OVX group

$C T R L=$ control fertile female rats, $\mathrm{OVX}=$ surgical ovariectomy, $\mathrm{E}_{2}$ : estrogen treatment, $\mathrm{R} 0.11 / \mathrm{R} 0.33 / \mathrm{R} 1=0.11 \mathrm{mg} / \mathrm{kg}, 0.33 \mathrm{mg} /$ $\mathrm{kg}, 1 \mathrm{mg} / \mathrm{kg}$ raloxifene treatment, $\mathrm{AVP}=$ arginine vasopressin.

Figure 1: Results are shown as means \pm S.E.M, $n=10$.

Figure 1 shows that OVX caused a significant increase in plasma AVP level in comparison with fertile females. Administration of $E_{2}$ $(0,10 \mathrm{mg} / \mathrm{kg} /$ day, per os) or RAL (in three different doses: $0,11 \mathrm{mg} /$ $\mathrm{kg} /$ day; $0,33 \mathrm{mg} / \mathrm{kg} /$ day; $1,0 \mathrm{mg} / \mathrm{kg} /$ day, per os) decreased the level of plasma AVP in OVX rat. Additionally, RAL treatment reduced the AVP level in a dose dependent way.

\section{Discussion}

Our findings show that $\mathrm{E}_{2}$ and RAL have an important role in the regulation of AVP level. Here, we demonstrated, that OVX resulted in a significant increase in the level of plasma AVP. Our findings are in accordance with a previous study that proved the increasing activity of AVP neurons in postmenopausal women [7]. We also proved, that this increased AVP content could be strongly reversed with $\mathrm{E}_{2}$ or RAL treatment. It has been reported earlier that RAL reduces blood pressure in hypertensive OVX rats [8]. These data are in line with a previous research by Daniela Grassi et al. [9], who found that AVP expression is highly regulated by raloxifene through the activation of G protein-coupled estrogen receptor- 1 in neuroblastoma cells. These results suggest that RAL 
has a significant role in the regulation of blood pressure. As a result of hormone deprivation, postmenopausal women tend to have a higher prevalence of hypertension which is the major risk factor of cardiovascular disorders [10]. As RAL has an estrogen-agonist effect on lipids and cardiovascular markers but acts as an estrogen antagonist in breast and uterus, therefore its administration demonstrates a potential therapeutic strategy for postmenopausal women.

\section{Acknowledgement}

This work was supported by the Ministry of Human Capacities 20391-3/2018/FEKUSTRAT, GINOP-2.3.2-15-2016-00062 and the European Union, co-financed by the European Social Fund (EFOP3.6.2-16-2017-00009).

\section{References}

1. Rosamond W, Flegal K, Furie K, Go A, Greenlund K, et al. (2008) Heart disease and stroke statistics-2008 update: a report from the American Heart Association Statistics Committee and Stroke Statistics Subcommittee. Circulation 117(4): e25-146.

2. Chen WY (2011) Postmenopausal hormone therapy and breast cancer risk: current status and unanswered questions. Endocrinol Metab Clin North Am 40(3): 509-518.

3. Sato M, MK Rippy, HU Bryant (1996) Raloxifene, tamoxifen, nafoxidine, or estrogen effects on reproductive and nonreproductive tissues in ovariectomized rats. FASEB J 10(8): 905-912.

\section{ISSN: 2574-1241}

DOI: 10.26717/BJSTR.2019.17.002969

Anikó Pósa. Biomed J Sci \& Tech Res

CC (9) This work is licensed under Creative Commons Attribution 4.0 License

Submission Link: https://biomedres.us/submit-manuscript.php
4. Walsh BW, Paul S, Wild RA, Dean RA, Tracy RP, et al. (2000) The effects of hormone replacement therapy and raloxifene on C-reactive protein and homocysteine in healthy postmenopausal women: a randomized, controlled trial. J Clin Endocrinol Metab 85(1): 214-218.

5. Nakano Y, Oshima T, Matsuura H, Kajiyama G, Kambe M (1998) Effect of 17 beta-estradiol on inhibition of platelet aggregation in vitro is mediated by an increase in NO synthesis. Arterioscler Thromb Vasc Biol 18(6): 961-967.

6. Galfi M, Radács M, Molnár Z, Budai I, Tóth G, et al. (2016) GhrelinInduced Enhancement of Vasopressin and Oxytocin Secretion in Rat Neurohypophyseal Cell Cultures. J Mol Neurosci 60(4): 525-530.

7. Ishunina TA, Kruijver FP, Balesar R, Swaab DF (2000) Differential expression of estrogen receptor alpha and beta immunoreactivity in the human supraoptic nucleus in relation to sex and aging. J Clin Endocrinol Metab 85(9): 3283-3291.

8. Moraes AN, Gouvêa SA, Gonçalves WL, Romero WG, Moyses MR, et al. (2011) Raloxifene reduces blood pressure in hypertensive animals after ovarian hormone deprivation. Basic Clin Pharmacol Toxicol 109(5): 334-338.

9. Grassi D, Ghorbanpoor S, Acaz Fonseca E, Ruiz Palmero I, Garcia Segura LM (2015) The Selective Estrogen Receptor Modulator Raloxifene Regulates Arginine-Vasopressin Gene Expression in Human Female Neuroblastoma Cells Through G Protein-Coupled Estrogen Receptor and ERK Signaling. Endocrinology 156(10): 3706-3716.

10. Lima R, M Wofford, JF Reckelhoff (2012) Hypertension in postmenopausal women. Curr Hypertens Rep 14(3): 254-260.

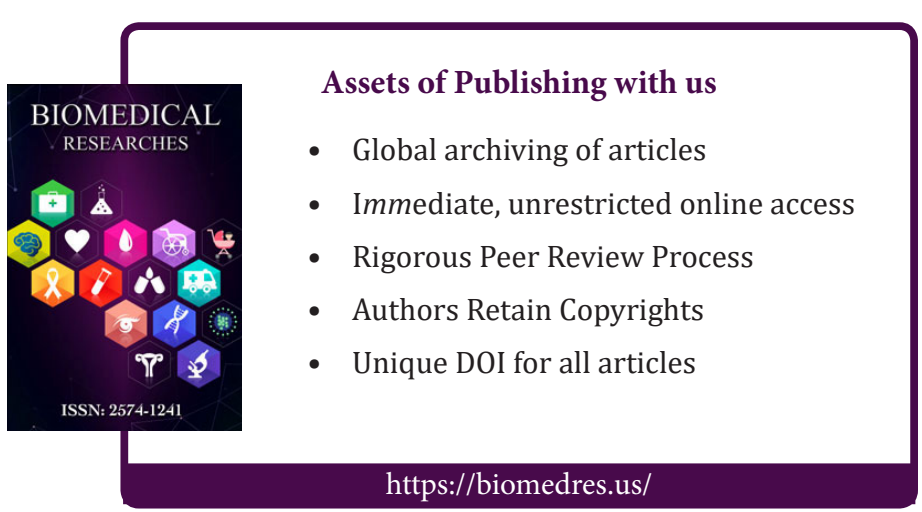

